\title{
COVID-19 in the Eastern Mediterranean Region: testing frequency, cumulative cases and mortality analysis
}

Pascale Salameh ${ }^{1,2,3}$

${ }^{1}$ Faculty of Public Health, Lebanese University, Fanar, Lebanon. ${ }^{2}$ Faculty of Medicine, Lebanese University, Hadat, Lebanon. ${ }^{3}$ INSPECT-LB: Institut National de Santé Publique, Epidémiologie Clinique et Toxicologie, Beirut, Lebanon. (Correspondence to: Pascale Salameh: pascalesalamehı@hotmail.com).

\begin{abstract}
Background: COVID-19 is now well documented in the Eastern Mediterranean Region; however, the incidence, mortality and fatality rates differ by country.
\end{abstract}

Aims: The study aimed to describe the COVID-19 pandemic in the Eastern Mediterranean Region, assessing the incidence, mortality-related and fatality rate in different countries, in comparison with the worldwide mean.

Methods: Data were sourced from the Worldometer surveillance page and from governmental reporting channels. Data were exported and analyzed using Statistical Package for Social Sciences (SPSS, version 23.0).

Results: In the Eastern Mediterranean Region, the testing frequency is heterogeneous between countries, in addition to the reported cases and death. Very few data are available from countries with political instability and security problems (Yemen, Syrian Arab Republic and Sudan), particularly for the testing frequency. Overall, despite similar rates of testing, there was a significantly lower incidence in the Eastern Mediterranean Region versus the rest of the world, in addition to a lower mortality per million-population, particularly in countries with low to moderate testing rates. However, in countries with higher testing than the world average, there is a higher incidence, a lower mortality, but an unexpected higher fatality rate.

Conclusion: The overall testing frequency was similar in the Eastern Mediterranean Region compared to the rest of the world; this would be expected to lead to a similar cumulative incidence and case fatality rate. Nevertheless, the average incidence was $70 \%$ lower than the rest of the world, and mortality per million-population was lower $(90 \%)$. Moreover, in Gulf Cooperation Council high-testing countries, a similar case-fatality rate to other countries in the Region was noted, but was higher than the world average, although expected to be lower. Further studies are necessary to explain discrepancies in incidence, mortality and fatality rates among countries; principally, environmental, genetic and managerial reasons should be investigated.

Keywords: COVID-19; testing rate; fatality; Middle East; incidence

Citation: Salameh P. COVID-19 in the Eastern Mediterranean Region: testing frequency, cumulative cases and mortality analysis. East Mediterr Health J. 2020;26(9):1005-1010. https://doi.org/10.26719/emhj.20.110

Received: 21/05/20; accepted: 18/08/20

Copyright @ World Health Organization (WHO) 2020. Open Access. Some rights reserved. This work is available under the CC BY-NC-SA 3.0 IGO license (https://creativecommons.org/licenses/by-nc-sa/3.o/igo)

\section{Introduction}

A newly discovered virus (SARS-CoV2) and its related disease (COVID-19) started in China in December 2019; it caused a pandemic that reached mainly high-income countries, but also a number of low and middle-income countries (1). COVID-19 was declared a pandemic by the World Health Organization (WHO) and has resulted in 2500448 cases and 171504 deaths (as of 21 April 2020) (2). There have been recorded cases in the Eastern Mediterranean Region (EMR) countries, but so far at a relatively lower rate.

The EMR Member States are Arab nations (3), in addition to Afghanistan, the Islamic Republic of Iran, and Pakistan. From a cultural perspective, the Region is primarily Islamic ( $90 \%$ of the population), and the vast majority of the population lives in low- to middle-income countries, with the notable exception of the high-income Gulf Cooperation Council (GCC) countries. Health care systems vary from one country to another according to gross domestic product and the size of the private versus public health sector (3). Although conditions in low- to middle-income countries theoretically increase the risk of exposure to the highly infectious coronavirus (overcrowding, low socioeconomic status and health care system preparedness), it appears there are in fact lower incidences of related infections (4). However, undertesting and/or under-reporting to international instances might offer possible explanations for this anomaly.

To date, it would appear no analytic work has been conducted concerning the magnitude of the COVID-19 pandemic in the Region, although data are available for all the countries (http://www.emro.who.int/health-topics/ corona-virus/index.html). Some recent articles analyzed and/or forecasted COVID-19 in individual countries such as Pakistan (5), Egypt (6), Gaza (7) and Sudan (8), but none did comparisons between the countries.

The objective of this study was to describe the COVID-19 pandemic in the EMR and assess the incidence, mortality-related and fatality rate in different EMR countries in comparison with the worldwide mean. 


\section{Methods}

Country data were taken from the Worldometer surveillance page - a data source that is run by an international team of developers, researchers and volunteers with the goal of making world statistics available in a thought-provoking and time relevant format to a wide audience around the world (2). COVID-19 data were collected via the site from official reports, government communication channels, and local media sources when deemed reliable.

Data were exported and analyzed using Statistical Package for Social Sciences (SPSS, version 23.0). To establish a basic concept, regression analysis was conducted on worldwide data, taking the case fatality rate as a dependent variable, while testing frequency and cumulative cases were used as independent variables; regression assumptions were checked.

For the EMR a descriptive analysis was conducted; means and standard deviations were reported, in addition to medians and interquartile ranges. Reporting results per million-population allowed a better comparison with global figures. t-tests were used to compare between the Region mean and the rest of the world mean incidence, mortality, fatality and testing frequency per million, after checking homoscedasticity assumption (in case of heterogeneous variances, the corrected t-test was used). In addition, the testing frequency of the Region was divided into tertiles, allowing to compare the mean incidence and mortality between countries with high, moderate and low testing frequency, using the KruskalWallis non parametric test, since the homoscedasticity assumption for using ANOVA was not met. Comparison with the world average was also conducted. A P-value $<0.05$ was considered significant.

\section{Results}

\section{Worldwide data}

On 21 April 2020 the mean cumulative number of cases was 681.53 cases per million persons $(S D=1566.84)$, while the mean case fatality rate was $4.82 \%(\mathrm{SD}=4.35)$. In addition, the mean number of tests per million/population was 9973.93 (SD=18405.75). The median [IQR] for these variables were respectively: $114.00[19.00 ; 607.00]$, $3.51[1.71 ; 6.31]$ and $3866[530.75 ; 11410.25]$.

However, the regression analysis applied to the world data showed that the case fatality rate could be represented using the following equation: Case fatality rate $=0.048$ $+8.056 .10^{-6}$ *cumulative cases/million-population $1.061^{*} 10^{-6 *}$ Tests/Million-population. The adjusted $\mathrm{R}$ square of this regression model was 0.121 , while the $P$-value for both factors was $<0.001$; the normality plots of residues were considered appropriate. The regression shows that the case-fatality rate was positively associated with reported cumulative cases (cumulative incidence), but negatively associated with testing frequency in the population. This result suggested that the higher the testing frequency, the lower the fatality rate.

\section{The Eastern Mediterranean Region}

The WHO EMR includes 22 countries: Afghanistan, Bahrain, Djibouti, Egypt, Islamic Republic of Iran, Iraq, Jordan, Kuwait, Lebanon, Libya, Morocco, Oman, Pakistan, Palestine, Qatar, Saudi Arabia, Somalia, Sudan, Syrian Arab Republic, Tunisia, the United Arab Emirates (UAE), and Yemen. The COVID-19 distribution in the Region is presented in Table 1. The highest numbers of cases were reported in the Islamic Republic of Iran, Saudi Arabia and Pakistan, while the lowest numbers were reported in Bahrain, Syrian Arab Republic and Yemen. As for case fatality numbers, Bahrain, Sudan and the Syrian Arab Republic reported the highest rates, while the lowest rates were shown in Kuwait, Djibouti and Qatar. Data for testing frequency were not available for all countries, namely Kuwait, Oman, Somalia, Sudan, Syrian Arab Republic and Yemen. Testing frequency was lowest for Afghanistan and Libya (<200 tests per million-population), and highest for Bahrain, Qatar and UAE (>20.00o tests/million-population) (Table 1).

\section{Comparison between Eastern Mediterranean Region and worldwide data}

Table 2 indicates comparison between EMR data and the rest of the world. Despite similar rates of testing, there was a significantly lower incidence in the EMR versus the rest of the world (cases per million-population), in addition to lower mortality per million-population and similar case-fatality rates (Table 2 ). It was noted that the ratios between the global and EMR figures were not proportionate; the incidence ratio was 2.90 , the mortality ratio 8.95 and the case fatality ratio was 1.24 .

\section{Comparison between Eastern Mediterranean Region countries and the rest of the world according to testing frequency}

Tertiles of testing frequency were the following: T1<1463 tests/million for Afghanistan, Libya, Egypt, Morocco, Pakistan, Tunisia (low testing rate); $1464<\mathrm{T} 2<4203$ tests/ million for Islamic Republic of Iran, Iraq, Jordan, Lebanon and Palestine (moderate testing rate); and T3>4204 test/million for Bahrain, Djibouti, Qatar, Saudi Arabia, and UAE (high testing rate).

Figure 1 presents the mean results of incidence, mortality and fatality rates according to the tertiles of testing frequency: $P$-value was 0.008 for incidence rates (higher cases/million were associated with higher testing frequency), while $P$-values were non-significant for mortality and fatality rates between EMR countries. It was noted that the mean case-fatality ratio is slightly but significantly higher than the world average ( $7.73 \mathrm{vs}$ $6.86 ; \mathrm{P}<0.001$ ).

Note: Kruskall-Wallis test was used. $P$-value $=0.008$ for incidence rates (higher cases/million were associated with higher testing frequency); $P$-values non-significant for mortality $(P=0.289)$ and fatality rates $(P=0.193)$ between EMRO countries. Case fatality rate significantly 


\begin{tabular}{|c|c|c|c|c|c|c|c|c|c|c|c|}
\hline Country & $\begin{array}{l}\text { Total } \\
\text { cases }\end{array}$ & $\begin{array}{l}\text { Total } \\
\text { deaths }\end{array}$ & $\begin{array}{l}\text { Total } \\
\text { recovered }\end{array}$ & $\begin{array}{l}\text { Active } \\
\text { cases }\end{array}$ & $\begin{array}{l}\text { Serious } \\
\text { critical }\end{array}$ & $\begin{array}{c}\text { Cases } \\
\text { /M }\end{array}$ & $\begin{array}{l}\text { Death } \\
\text { /M }\end{array}$ & $\begin{array}{c}\text { Total } \\
\text { test }\end{array}$ & Test/M & $\begin{array}{l}\text { Millions } \\
\text { population }\end{array}$ & $\begin{array}{c}\text { Reported } \\
\text { Fatality } \\
\text { rate }\end{array}$ \\
\hline Bahrain & 1907 & 7 & 769 & 1131 & 2 & 1121 & 4 & 89225 & 52437 & 1.70156568 & 0.0037 \\
\hline Sudan & 107 & 12 & 8 & 87 & & 2 & 0.3 & & & & 0.1121 \\
\hline Syrian Arab Republic & 39 & 3 & 5 & 31 & & 2 & 0.2 & & & & 0.0769 \\
\hline Egypt & 3333 & 250 & 821 & 2262 & & 33 & 2 & 55000 & 537 & 102.4208566 & 0.0750 \\
\hline $\begin{array}{l}\text { Islamic Republic of } \\
\text { Iran }\end{array}$ & 83505 & 5209 & 59273 & 19023 & 3389 & 994 & 62 & 353012 & 4203 & 83.99048299 & .0624 \\
\hline Iraq & 1574 & 82 & 1043 & 449 & & 39 & 2 & 59055 & 1468 & 40.22820163 & 0.0521 \\
\hline Morocco & 3046 & 143 & 350 & 2553 & 1 & 83 & 4 & 16386 & 444 & 36.90540541 & 0.0469 \\
\hline Tunisia & 884 & 38 & 148 & 698 & 34 & 75 & 3 & 17287 & 1,463 & 11.81613124 & 0.0430 \\
\hline Somalia & 237 & 8 & 4 & 225 & 2 & 15 & 0.5 & & & & 0.0338 \\
\hline Afghanistan & 1092 & 36 & 150 & 906 & 7 & 28 & 0.9 & 6422 & 165 & 38.92121212 & 0.0330 \\
\hline Yemen & 1 & & & 1 & & 0.03 & & & & & 0.0330 \\
\hline Lebanon & 677 & 21 & 103 & 553 & 27 & 99 & 3 & 20929 & 3,066 & 6.82615786 & 0.0310 \\
\hline Pakistan & 9216 & 192 & 2066 & 6958 & 46 & 42 & 0.9 & 111806 & 506 & 220.9604743 & 0.0208 \\
\hline Libya & 51 & 1 & 15 & 35 & & 7 & 0.1 & 808 & 118 & 6.847457627 & 0.0196 \\
\hline Jordan & 425 & 7 & 282 & 136 & 5 & 42 & 0.7 & 33000 & 3234 & 10.20408163 & 0.0165 \\
\hline Saudi Arabia & 10484 & 103 & 1490 & 8891 & 88 & 301 & 3 & 180000 & 5170 & 34.81624758 & 0.0098 \\
\hline Palestine & 461 & 4 & 71 & 386 & & 90 & 0.8 & 17329 & 3397 & 5.101265823 & 0.0087 \\
\hline United Arab Emirates & 7265 & 43 & 1360 & 5862 & 1 & 735 & 4 & 790000 & 79875 & 9.890453834 & 0.0059 \\
\hline Oman & 1,508 & 8 & 238 & 1262 & 3 & 295 & 2 & & & & 0.0053 \\
\hline Kuwait & 1995 & 9 & 367 & 1619 & 39 & 467 & 2 & & & & 0.0045 \\
\hline Djibouti & 846 & 2 & 102 & 742 & & 856 & 2 & 8144 & 8243 & 0.98798981 & 0.0024 \\
\hline Qatar & 6015 & 9 & 555 & 5451 & 37 & 2088 & 3 & 64620 & 22429 & 2.881091444 & 0.0015 \\
\hline
\end{tabular}

different between high testing countries and worldwide average $(P<0.001)$.

\section{Discussion}

In the Region the testing frequency is heterogeneous between countries, in addition to the reported cases and mortality rates. Data from individual countries were similar to that described by Dil et al. (5). Limited data were available from countries with political instability and security problems (Yemen, Syrian Arab Republic and Sudan), particularly for the testing frequency.
In this analysis, it is shown that globally the casefatality rate is positively associated with reported cumulative cases (cumulative incidence), but negatively associated with testing frequency in the population. However, in the Region the testing frequency was similar on average to that reported in the rest of the world; this would be expected to lead to a similar cumulative incidence and case fatality rate. Nevertheless, the incidence in the EMR versus the rest of the world was lower by two thirds, whereas mortality per millionpopulation was lower by $90 \%$; only case-fatality rate

Table 2 COVID-19 cases cumulative incidence, mortality and testing comparison between Eastern Mediterranean Region and the rest of the world (average)

\begin{tabular}{|c|c|c|c|c|c|c|c|c|}
\hline Region & $\begin{array}{c}\text { Total } \\
\text { population in } \\
\text { million }\end{array}$ & Total cases & $\begin{array}{l}\text { Total } \\
\text { deaths }\end{array}$ & $\begin{array}{l}\text { Mean } \\
\text { cases per } \\
\text { million }\end{array}$ & $\begin{array}{c}\text { Mean } \\
\text { death per } \\
\text { million }\end{array}$ & $\begin{array}{c}\text { Mean } \\
\text { reported } \\
\text { fatality rate } \\
(\%)\end{array}$ & $\begin{array}{l}\text { Reported } \\
\text { total } \\
\text { tests }\end{array}$ & $\begin{array}{l}\text { Mean } \\
\text { reported } \\
\text { tests per } \\
\text { thousand }\end{array}$ \\
\hline $\begin{array}{l}\text { Eastern } \\
\text { Mediterranean } \\
\text { Region }\end{array}$ & 700 & 125108 & 6252 & 251.27 & 4.73 & 4.00 & 1606714 & 8.45 \\
\hline Rest of the World & 7779 & 2205685 & 154391 & 727.56 & 42.35 & 4.96 & 18240910 & 10.16 \\
\hline $\mathrm{P}$-value & & & & $0.002^{*}$ & $0.001^{*}$ & $0.733^{* *}$ & & $0.347^{* *}$ \\
\hline
\end{tabular}

${ }^{*} P$-value was calculated using corrected Student testing (variances were heterogeneous).

${ }^{* *}$-value was calculated using Student testing (variances were homogeneous). 


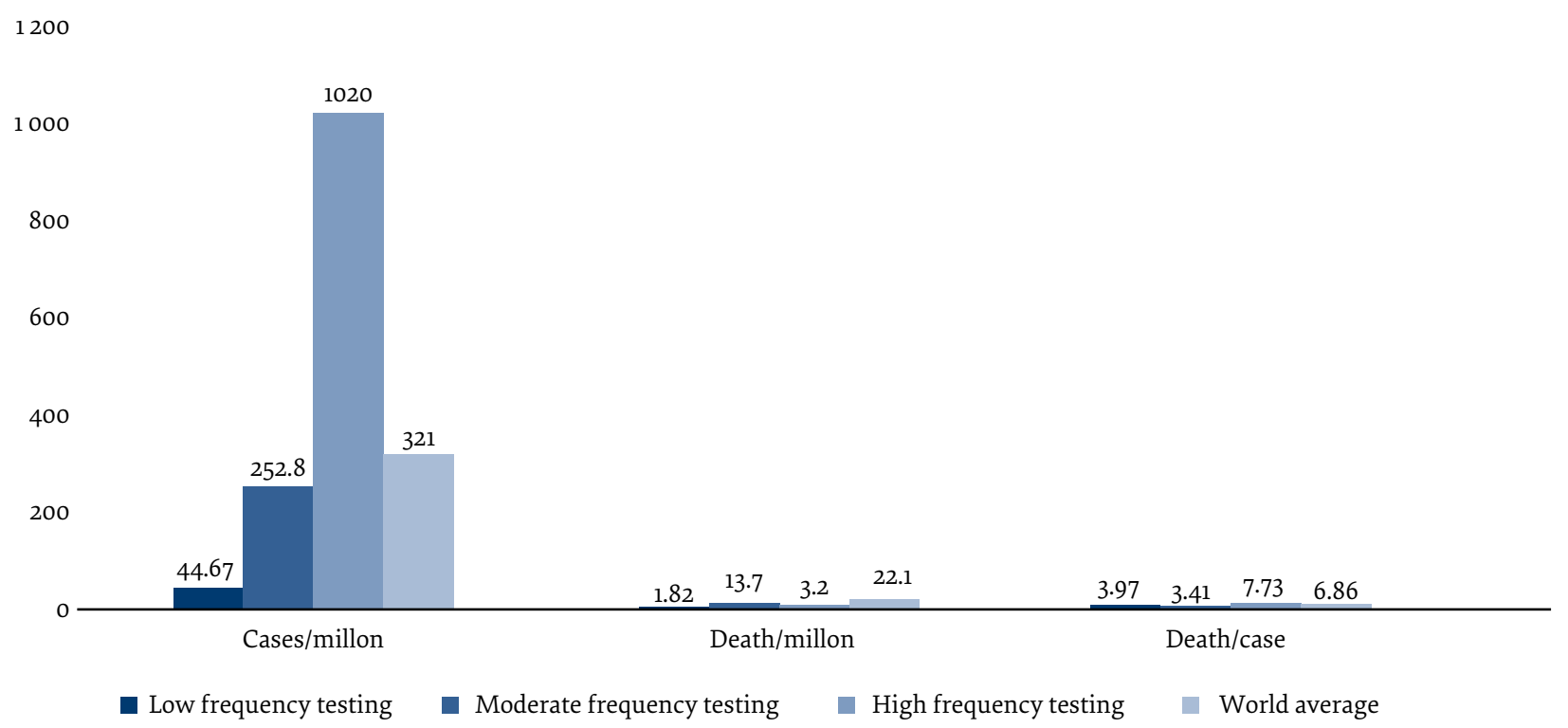

was similar. These results could be explained by high heterogeneity in terms of testing frequency.

In fact, when dividing the countries into tertiles of testing, results became clearer. In high-testing countries (higher than the world average testing rate), there was a higher incidence and similar mortality, which is expected according to the regression model. In addition, high-testing rates were expected to decrease overall fatality rate; the examples of Germany and South Korea are striking in this regard (9). Higher testing should generally lead to better identification of cases and to their early isolation, in addition to their contact tracing, which are related to lower fatality rate (10). Nevertheless, the fatality rate that was found in these countries was expected to be lower than other countries; however, this was not the case and was significantly higher than that of the world average.

This finding was intriguing, particularly knowing that these nations are high-income countries in general (GCC countries), with reported stricter confinement measures and an expected better health system (11). It is noted that some of these countries still witness community cases and hospital-acquired infections of Middle East Respiratory Syndrome coronavirus (MERS$\mathrm{CoV})$. This could present a significant challenge to dealing effectively with both coronaviruses, especially with the lack of standardized and approved point of care testing (12). Further studies are suggested to explain this unexpected result of higher fatality rate in high-testing Middle Eastern countries, looking at specific factors such as chronic diseases prevalence (cardiovascular or respiratory) (13), viral mutation, genetic variability, discrepancies in COVID-19 related death definition, and possible inappropriate tertiary care management (14).

In countries with moderate testing rates (close to the world average testing rates), there were lower incidence, mortality and fatality rates; these figures were significantly higher in countries with low testing rates. These results could denote either true lower incidence (and subsequent mortality) versus the world average; the Region might have conditions that favour a lower incidence of the disease; climatic factors (currently hotter than European and North American countries); more conservative social behaviours; viral mutation; or ethnic/ genetic variations. Another more probable explanation would be under-notification of cases due to under testing in these countries, particularly under-notification of COVID-19 related death. Improvement in testing and notification is required to better judge the epidemic situation in these countries.

\section{Limitations}

The study took into account cases from the beginning of the pandemic until 21 April 2020; figures, case reporting, tests and many parameters may change with time. The study also relied on cumulative numbers of cases, death and testing rates, without taking time and the duration of the epidemics in specific countries into account. Thus, a change in testing rates could change the interpretation of epidemic curves (15). In addition, the study did not take into account the prevention measures applied by every country (16) and their effect on the epidemic curve. Security issues prevented availability of all data; thus, the results could underestimate the true burden of COVID-19 in the Region.

\section{Conclusion}

The overall testing frequency was similar in the EMR compared to the rest of the world. This would be expected to lead to a similar cumulative incidence and case fatality rate. However, the average incidence was $70 \%$ lower than the rest of the world, and mortality per million-pop- 
ulation was lower (90\%). Moreover, in GCC high-testing countries, a strikingly similar case-fatality rate to other countries in the world - and even higher than the world average - was indicated, although expected to be lower. Increasing the frequency of testing and improving notification of cases and of death is a necessity in order to better assess the situation in the EMR. In addition, taking into account country specificities would also offer greater insight into the COVID-19 situation in the Region.

Funding: None.

Competing interests: None declared.

\section{La COVID-19 dans la Région de la Méditerranée orientale : fréquence des tests, cas cumulés et analyse de la mortalité}

\section{Résumé}

Contexte : La COVID-19 est maintenant bien documentée dans la Région de la Méditerranée orientale ; cependant, les taux d'incidence, de mortalité et de létalité diffèrent selon les pays.

Objectifs : La présente étude avait pour objectif de décrire la pandémie de COVID-19 dans la Région de la Méditerranée orientale, en évaluant les taux d'incidence, de mortalité et de létalité dans différents pays, en comparaison avec la moyenne mondiale.

Méthodes : Les données proviennent de la page de surveillance de Worldometer et des canaux de communication gouvernementaux. Elles ont été exportées et analysées au moyen du logiciel Statistical Package for Social Sciences (SPSS, version 23.0).

Résultats : Dans la Région de la Méditerranée orientale, outre les cas notifiés et les décès, la fréquence des tests est hétérogène entre les pays. Très peu de données sont disponibles pour les pays connaissant une instabilité politique et des problèmes de sécurité (République arabe syrienne, Soudan et Yémen), en particulier pour la fréquence des tests. Globalement, malgré des taux de dépistage similaires, on a observé une incidence considérablement plus faible dans la Région de la Méditerranée orientale par rapport au reste du monde, en plus d'une mortalité plus faible par million d'habitants, en particulier dans les pays où les taux de dépistage sont faibles à modérés. Cependant, dans les pays où le dépistage est plus fréquent que la moyenne mondiale, on observe une incidence plus élevée, une mortalité plus faible, mais un taux de létalité plus élevé, de manière inattendue.

Conclusion : La fréquence globale des tests était similaire dans la Région de la Méditerranée orientale par rapport au reste du monde, ce qui devrait entraîner une incidence cumulée et un taux de létalité similaires. Néanmoins, l'incidence moyenne était inférieure de $70 \%$ à celle du reste du monde ainsi que la mortalité par million d'habitants (90\%). En outre, dans les pays du Conseil de Coopération du Golfe ayant une fréquence de tests élevée, un taux de létalité similaire à celui d'autres pays de la Région a été constaté ; toutefois, ce taux était supérieur à la moyenne mondiale, même s'il était inférieur aux prévisions. Des études plus approfondies sont nécessaires pour expliquer les différences des taux d'incidence, de mortalité et de létalité entre les pays ; il convient principalement d'étudier les raisons environnementales, génétiques et administratives.

$$
\text { كوفيد-19 في إقليم شرق المتوسط: تواتر الاختبار، و الحالات التراكمية، وتحليل الوفيات }
$$

الخلفية: لقد جرى توثيق كوفيد-19 الآن توثيقًا جيدًا في إقليم شرق المتوسط؛ لكن معدلات الحدوث والوفيات و الوفيات بين

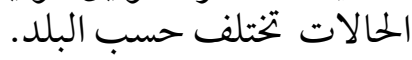

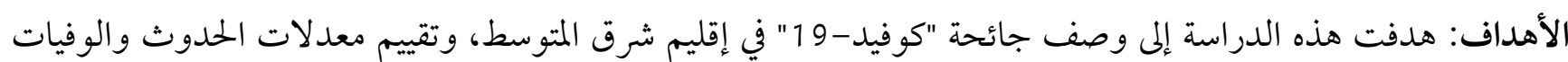

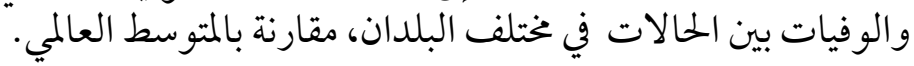

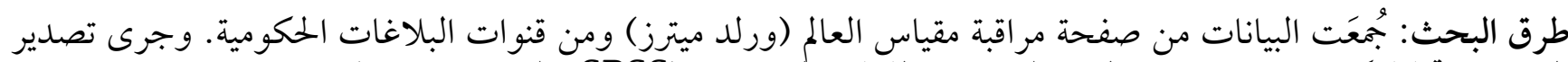

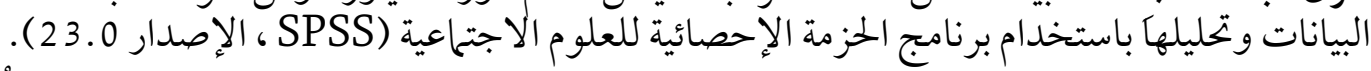

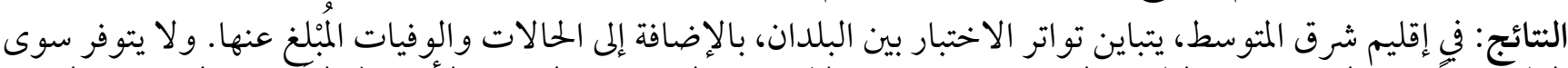

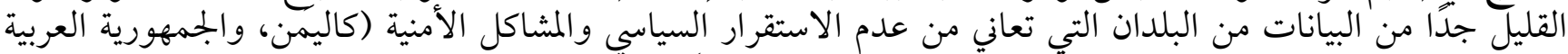

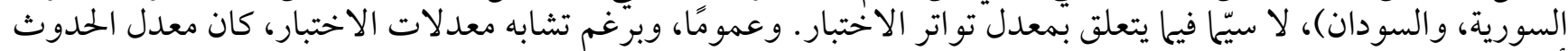

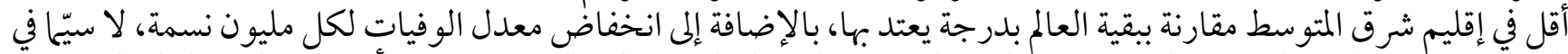

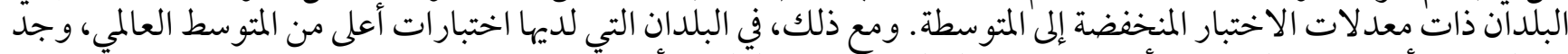

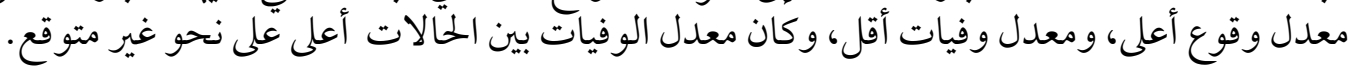


الاستنتاج: كان معدل تواتر الاختبار الإجمالي مماثلاً في إقليم شرق المتوسط مقارنة ببقية العالم؛ ومن المتوقع أن يؤدي ذلك ذلك إلى إلى

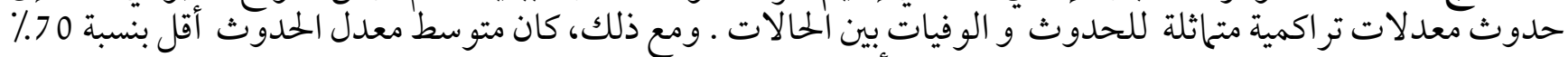

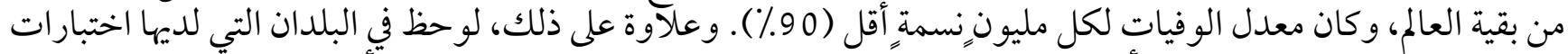

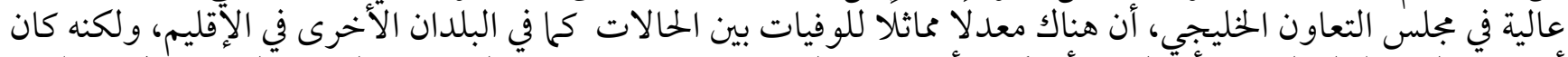

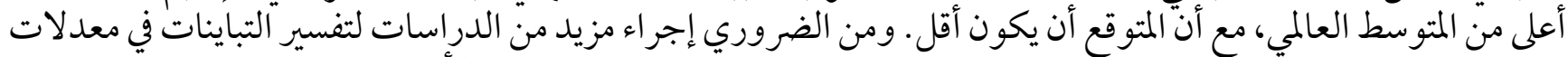

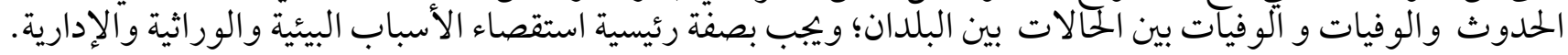

\section{References}

1. Sohrabi C, Alsafi Z, O’Neill N, Khan M, Kerwan A, Al-Jabir A, et al. World Health Organization declares global emergency: A review of the 2019 novel coronavirus (COVID-19). Int J Surg Lond Engl. 2020 Feb 26;76:71-6.

2. Worldometer. April 2020. (https://www.worldometers.info/coronavirus/).

3. Alsharif, NZ, Khanfar NM, Brennan LF, Chahine EB, Al-Ghananeem AM, Retallick J, et al. 2019. Cultural Sensitivity and Global Pharmacy Engagement in the Arab World. Am J Pharm Educ 2019;83(4):7228. doi: 10.5688/ajpe7228.

4. Guo Y, Huang YM, Huang J, Jin YZ, Jiang W, Liu PL, et al. COVID-19 pandemic: global epidemiological trends and China's subsequent preparedness and responses. Zhonghua Liu Xing Bing Xue Za Zhi Zhonghua Liuxingbingxue Zazhi. 2020 May 10;41(5):642-647. doi: 10.3760/cma.j.cn112338-20200301-00222

5. Dil S, Dil N, Maken ZH. COVID-19 trends and forecast in the Eastern Mediterranean Region with a Particular Focus on Pakistan. Cureus. 2020;12(6):e8582. 2020 Jun 12. doi:10.7759/cureus.8582

6. Radwan GN. Epidemiology of SARS-CoV-2 in Egypt. East Mediterr Health J. 2020 Jul 1;26(7):768-73. https://doi.org/10.26719/ emhj.20.084

7. Alser O, AlWaheidi S, Elessi K, Meghari H. COVID-19 in Gaza: a pandemic spreading in a place already under protracted lockdown. East Mediterr Health J. 2020 Jul 1;26(7):762-3. https://doi.org/10.26719/emhj.20.089

8. Gasmelseed YA, Mohamed Y, Adulhameed R, Ishag M, Elzubair AG. Controlling the spread of COVID-19 in Sudan with limited resources: a unique community-engaged approach. East Mediterr Health J. 2020;26(6). https://doi.org/10.26719/emhj.20.072

9. Jee Y. WHO International Health Regulations emergency committee for the COVID-19 outbreak. Epidemiol Health. 2020;42:e2020013. doi:10.4178/epih.e2020013

10. Salathé M, Althaus CL, Neher R, Stringhini S, Hodcroft E, Fellay J, et al. COVID-19 epidemic in Switzerland: on the importance of testing, contact tracing and isolation. Swiss Med Wkly. 2020 Mar 19;150:w20225. doi: 10.4414/smw.2020.20225

11. Briefs VI, Books VI. COVID-19: Developments in West Asia. (https://www.vifindia.org/article/2019/april/o3/covid-19-developments-in-west-asia?slide $=\$$ slideshow\$).

12. Barry M, Al Amri M, Memish ZA. COVID-19 in the shadows of MERS-CoV in the Kingdom of Saudi Arabia. J Epidemiol Glob Health. 2020;10(1):1-3. doi:10.2991/jegh.k.200218.003

13. Alshaikh MK, Filippidis FT, Al-Omar HA, Rawaf S, Majeed A, Salmasi AM. The ticking time bomb in lifestyle-related diseases among women in the Gulf Cooperation Council countries; review of systematic reviews. BMC public health. 2017 Dec;17(1):536.

14. Ram P. Management of healthcare in the Gulf Cooperation Council (GCC) countries with special reference to Saudi Arabia. IJARBSS. 2014 Dec 1;4(12):24.

15. Omori R, Mizumoto K, Chowell G. Changes in testing rates could mask the novel coronavirus disease (COVID-19) growth rate [published online ahead of print, 2020 Apr 19]. Int J Infect Dis. 2020;S1201-9712(20)30236-8. doi:10.1016/j.ijid.2020.04.021

16. Güner R, Hasanoğlu I, Aktaş F. COVID-19: Prevention and control measures in community. Turk J Med Sci. 2020;50(SI-1):571-577. Published 2020 Apr 21. doi:10.3906/sag-2004-146 